\title{
治療効果よりみた慢性気管支炎の臨床的分類
}

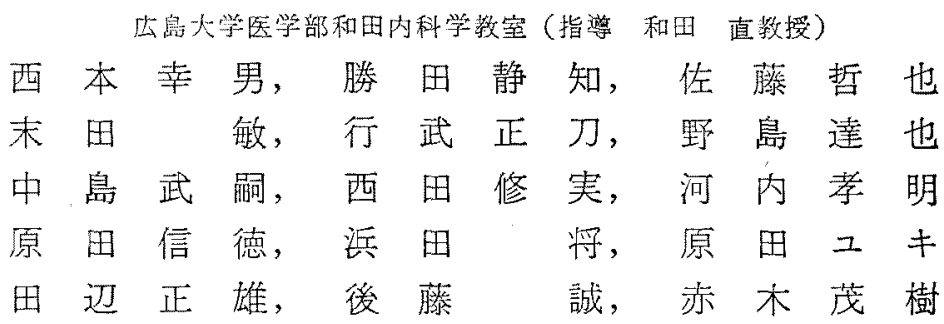

\section{CLINICAL CLASSIFICATION OF CHRONIC BRONCHITIS FROM THE THERAPEUTIC STAND POINT OF VIEW}

\author{
Yulkio Nishimoto, Shizutomo Katsuta, Tetsuya Sato, Satoshi Sueda, \\ Masato Yumutake, Tatsuya NoJma, Taketsugu Narashrma, \\ Osami Nisuida, Takaaki Kovcm, Nobunori HaRAdA, \\ Susumu Hamada, Yuki Harada, Masao Tanabe, \\ Makoto Goto and Shigeki AkAGI
}

Department of Internal Medicine, Hiroshima University School of Medicine

(Director: Professor Sunao Wada, M.D.)

\begin{abstract}
概要 慢性気管支炎涊, 上うやく,わが国の呼吸器疾患の中で重要な疾患の一つに数えられるべき状態

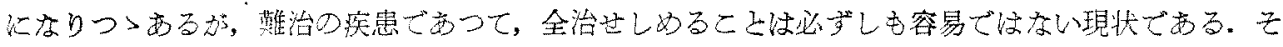

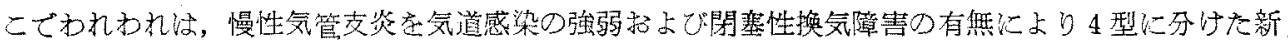

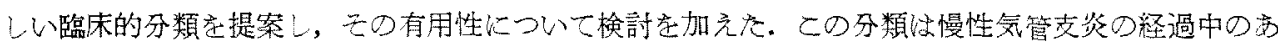

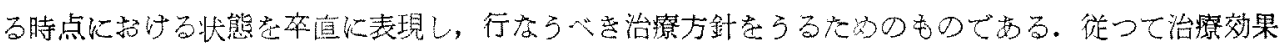
のい玑んよつては，ある型加他の型へ移行する場合もありうる，上ああ机，慢性気管支炎之診断

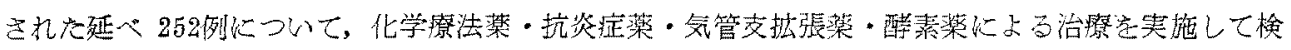

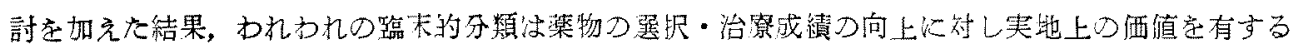
あのであるととが判明した。
\end{abstract}

\section{I. 緒 言}

慢泩気管支炎は，従来，その定義が明瞭でな く、診断する医師により，また，国により，概念 が異孛つていて，いわば慢性㭔吸器疾患の墓場の ごとき印笙すら与えていたものであつた．しかし ながら，近年に至つて，わが国においても慢性気 管支炎に対する認識がにわかに高まつて来つ〉あ る.この傾向に対しては数多くの理由を学价うる ものと思われるが，まず、第一に，慢性気管支炎 分慢性肺気腫・肺線維症・気管支拡張症等のい方
ゆる非特異性慢性呼吸器疾患の基礎族患として重 要であることが認識されて来たこと，第 2 に，わ が国の産業ならびに生活程度が急速に向上し て，大気の活染が米国を始めとする文明国のそれ に近づいて来たこと，第3には，平均寿命の延長 により慢性気管支炎の好発年 令で㐫る高年者が 增加していることなとが挙げられよう。ともあ れ，慢性気管支炎は，上うやくわが国の㭔吸器疾 急の中で，重要な疾㭧の一つに数えられるべき状 態になりつ>あることは否めない事実のようであ 
る，徒つて，これ方效簀は緊急を要するものであ

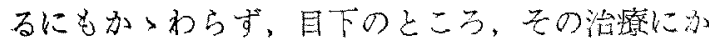
んして決定的な与剱注確立されていない現状であ る.

ところで，和狈れは，現在，抗生钧質・副繁 皮貿ステロイド・気管支抬張蒋・蛋白融解酵素学 どの諸腫薬物による系統的な研究を継続中で市 り，その成績の一部は昭和38年10月，第3回日本 胸部疾患学会総会において無表1〉した。今回はを の第二段階として治療を目標とした慢性気管支炎 の分類法を提唱し，あわ技て二，三の検討を加え たのでその大要を報告する。

\section{II. 慢性気管支炎に対するわれわれの臨床的} 分類

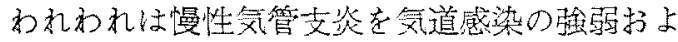
び開塞性換気障害の有無により䒾 1 のごとく4型

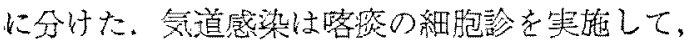
膘球数およびいわゆる核總2)の多宾により制定し たが，気道感染の强いものは後述の判定で（十）

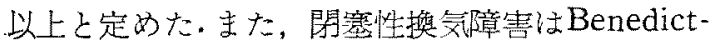
Roth型レスピロターターを用い，1秒率㧍よび最 大換受量比が，它れぎれ700.0およじ80\%以下のも のとした。

第 I 型： 肺機能䄸査において閉塞性換気障害 を認めず，客寗娭查において気道感 染の所見が著明でないもの.

第 I 型：阿塞性換気障害を訛めないが，咯痰 に気道感染の所見が顯著なもの。

第且型： 閉塞性換気障害が明らかであるが， 気道感染の所見が著明でないもの.

第 $\mathbb{V}$ 型：閉塞性換気障害・気道感染の所見が ともに明らかであるもの。

表 1 . 慢性氮管支炎の臨床的分類

\begin{tabular}{|c|c|c|c|}
\hline & \multicolumn{2}{|c|}{ 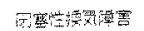 } \\
\hline & & 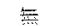 & 有 \\
\hline \multirow{2}{*}{ 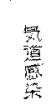 } & 弱 & I 型 & 西型 \\
\hline & 強 & II型 & 严 \\
\hline
\end{tabular}

\section{III. 検查対象}

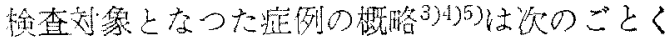
である。

昭和 4 年方ら終线に至るまでの闃，広岛景竹原 市に所属する大久野島に装置されていた旧陸軍唯

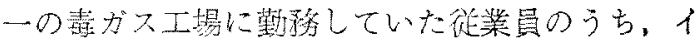
ペリット・ルイサイト等の猛静ガスを繁造し，あ るい㛎，その土場内での機珹修理に当つていたも のの大部分注，絎20年孝経た今日に扮いても，な

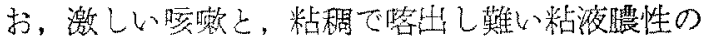
喀疼存し，冬期には症状の要化索繰り返してい

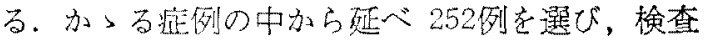
の対象とした。症例の唔床的分類例数は表 $20 こ ゙$ と々，管 I 型96例，第 II 型87例，第 III 型30例，第 N型39例であつた。

\begin{tabular}{|c|c|c|c|c|c|}
\hline 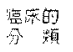 & I型 & II 型 & 正玨 & W 型 & 訪 \\
\hline $41 \mathrm{z}$ & 96 & 87 & 30 & 39 & 252 \\
\hline
\end{tabular}

\section{IV. 梌查方法}

A. 使用薬物の稙類・投与方法ならびに投与期 間

萫物の投与期間はいずれも4週間とし，使用楽 物によりとのごとく6 群に分けた。

1. 化学療法群：使用莉物としては次の3 種

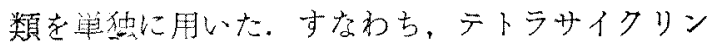
とオレアンドマイシンの合剤 1 日 $1 \mathrm{~g} 4$ 回分服， フェノキシエチルペニシリン・カリウム20万笚位

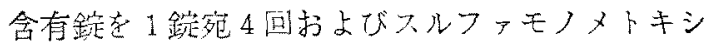
ン1 gを1日1回服用した。

2. クロロキン群：クロロキン・ジオロテー

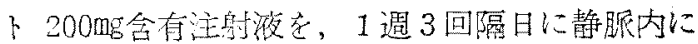
注射した。

3.ステロイド群：副腎度質ステロイドとし てはベーターメサソン $1 \mathrm{mg}$ 朝多 2 回に分服し た.

4. 気管支昖張薬群：1-(3，5ージヒドロキ シフェニール）-2-イソプロピルアミノエタノー

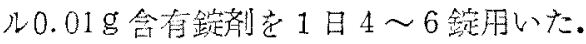


5.その他の浆物群： 蛋白融解醋素己して キモトリブシン25骂バッカルを1日4錝，あるい は抗ブラスミン蒋であると-アミノカプロン酸 $3 \mathrm{~g}$ を1日3回分服.

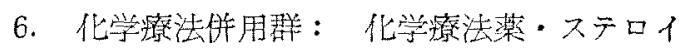

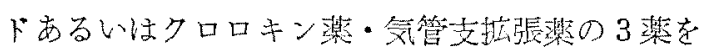
併用した。化学潦法萝としてはテトラサイクリン とオレアントママタンの合威抢よび一部の症例に 対してはスルファモノタトキシンを用い，使用量

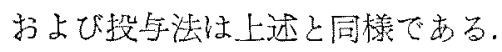

\section{B. 臨床諸㮥查の实施方法}

いすれれの症例においても，楽北投与開始前，開 始 2 週間後むよび 4 週間後に自覚症状の調查, 呶

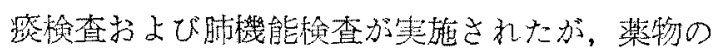

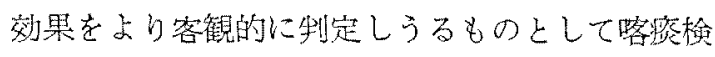
查扔よび肺機能検查を採用したので，その梌查方 法ならびに判定基準等について略述する。

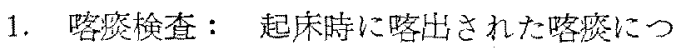
いて，肉眼的性状・潜血反応を蚞查し，かつ潩捇

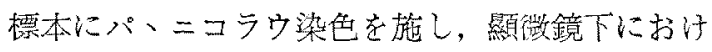

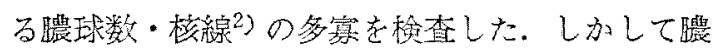
球数においては，平均方ると每視野10個以上の澧 球を認めるものを（十）とし，100個以上を（H） とした。また，核楾も每視野にかたり明らかな 核線を認好方孔ものを(十)、多数認めるものを (H) とした.

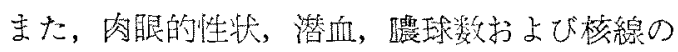
4 項目について, その推移を項目每に性定し, 改 善を+1点，惡化を一1点として椙殺した。その 結果, $+3 \sim 4$ 点萻し改善 $(S S),+1 \sim 2$

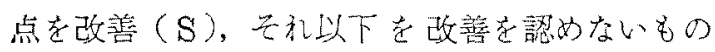

(s) とした。

2. 肺機能湌查： Benedict-Roth型レスピロ メーターにより全例にスパイログラフィー安実施 l, 肺活量, 1 秒㳯, 最大哹気中閐流量 (MMF) 抢よび最大換気量（MBC）の測定を行なつた。

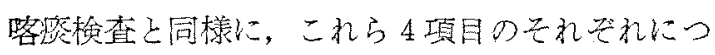
いて推移をみたが，そのさい，肺活量拉よび1秒 量については 100cc以上の増堿, MMFについて
は $0.3 l / \mathrm{sec}$ 上, MBCについては3 $l / \mathrm{min}$ 上上 の增減を以て改善あるい恓化と利定した。しか して上述のごとく相殺した結果， $+3 \sim 4$ 点を著 しい改善 (FF)，+1〜2点を改善 (F)，それ 以下を改善を認めないもの（f）とした。

\section{V. 諸種薬物投与時における喀痰および肺機能} 所見の推移

\section{A. 化学療法群 (表 3参照)}

北学療法を算独に実施した45例を，われわれの 臨床的分類别にみると，第I型19例，第而型17 例，第四型 5 例，第V型4 例であった。

各種の化学潦法然を 4 週間投与した後における

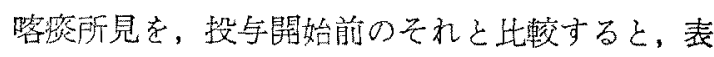

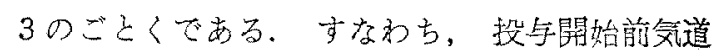
感染の顯著であつた第扛型おる゙第双型において は，約革数例において著しい改善（S S ）がみら れ，改善をみない（s）ものは第师型の1例に過 ぎなかつた。これによし，気道感染の㬎著でなか つた第I型およで第而型に抒いては（）と制定 された例が多かつた。

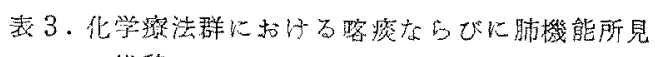
の推移

\begin{tabular}{|c|c|c|c|c|c|c|c|}
\hline \multirow{2}{*}{ 復底的分期 } & \multirow{2}{*}{ 庭例数 } & \multicolumn{3}{|c|}{ 喀㾳所胃 0 推移 } & \multicolumn{3}{|c|}{ 剈摧能所兒の㩲移 } \\
\hline & & SS & $S$ & $s$ & FF & $F$ & $f$ \\
\hline I型 & 19 & 4 & $\begin{array}{l}6 \\
(31.6) \\
\end{array}$ & $\begin{array}{l}9 \\
(47,3)\end{array}$ & $\begin{array}{l}2 \\
(10.5) \\
\end{array}$ & 5 & $\begin{array}{l}12 \\
63.2)\end{array}$ \\
\hline II 型 & 17 & $\begin{array}{l}8 \\
(47.1)\end{array}$ & 9 & 0 & $(5.9)$ & $5.29 .4)$ & $(64.7)$ \\
\hline 亚型星 & 5 & 0 & $\begin{array}{l}1 \\
(20.0)\end{array}$ & $\begin{array}{l}4 \\
(80.0)\end{array}$ & $\begin{array}{l}1 \\
(20.0)\end{array}$ & $\begin{array}{l}1 \\
(20.0)\end{array}$ & 3 \\
\hline ID型 & 4 & 2 & $\begin{array}{l}1 \\
(25.0)\end{array}$ & $\frac{1}{(25.0)}$ & 0 & 0 & $\begin{array}{l}4 \\
(100.0)\end{array}$ \\
\hline 計 & 45 & 14 & $\begin{array}{l}17 \\
(37.8)\end{array}$ & $\begin{array}{l}14 \\
(31.1)\end{array}$ & $4(8.9)$ & $(24.4)$ & $306.7)$ \\
\hline
\end{tabular}

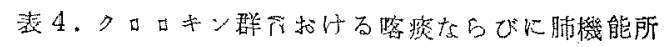
見の推移

\begin{tabular}{|c|c|c|c|c|c|c|c|}
\hline & \multirow{2}{*}{ 症例散 } & \multicolumn{3}{|c|}{ 暥璒所完 $\sigma$ 推移 } & \multicolumn{3}{|c|}{ 炜機能所見の推移 } \\
\hline & & SS & $S$ & $s$ & $F F$ & $F$ & $f$ \\
\hline I 型 & 16 & $3_{(18.7)}$ & 5 & ${ }^{8}(50.0)$ & ${ }^{1}(6.2)$ & $\begin{array}{l}6 \\
(37.5)\end{array}$ & 9 \\
\hline II 型 & 17 & $3(17.6)$ & $\begin{array}{l}9 \\
(53.0)\end{array}$ & $5(29,4)$ & ${ }^{1}(5.9)$ & $\begin{array}{l}3 \\
(17.6) \\
\end{array}$ & $\begin{array}{l}73 \\
(76.5)\end{array}$ \\
\hline III 型 & 6 & $(16.7)$ & ${ }^{3}(50.0)$ & ${ }^{2}(33.3)$ & 0 & $\begin{array}{l}2 \\
(33.3) \\
\end{array}$ & $4(66.7)$ \\
\hline IV 型 & 10 & $\begin{array}{l}1 \\
(10.0) \\
\end{array}$ & $\begin{array}{r}4 \\
(40.0) \\
\end{array}$ & $5(500)$ & $(10.0)$ & $6(60.0)$ & $\begin{array}{l}3 \\
(30.0) \\
\end{array}$ \\
\hline 馀一 & 49 & $\begin{array}{l}8 \\
(16.3)\end{array}$ & $21(42.9)$ & $\begin{array}{r}20 \\
(40.8)\end{array}$ & $3(6.1)$ & $\begin{array}{l}17 \\
(34.7)\end{array}$ & 29 \\
\hline
\end{tabular}


肺機能所見は一般に改善をみる例が少なく，第 I 型，第型，第开型においては約60\%方改善を みない（f）と籼定され，第 $\mathbb{V}$ 型においては全例 （f）と制定された。

B. クロロキン群（表 4 参照）

クロロキン薬を静注した49例の臨床的分類は， 表 4 のごとく，第 I 型16例，第II型17例，第型 6 例，第V型10例であつた。

喀㡾所見の推移をみると，幔性気管支炎の各型 とも著しい改善（S S）をみたのは20\%以下々い う少数例に止まり，改善（S）を含めて過半数の

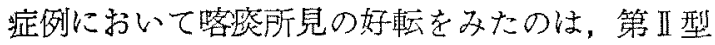
および第丑型であつた。

肺機能所見の推移をみると，著しい改善(F F) は10\%内外という低率であつたが，改善（F）を 含めて帕機能所見の好転が比較的高摔であつたの は第型であつた。

\section{C．ステロイド群（表 5 参照）}

ベーターメサゾンを投与した29例の臨末的分類

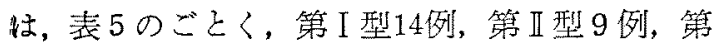
II 型 2 例, 第V型 4 例であつた。

喀痰所見の推移をみると，著しい改善（SS） は第型にみられのみであつた。しかしながら 政善（S）を含めると、いずれの型でも約半数例 に改善がみられていた。

眠機能所見では，第芷型は 2 例とも改善がみら れず（f），第正型に扔いても 1 例を除き他はす心゙ て（f）と制定された、しかしながら第伎型におい ては著しい改善（FF）こをみられなかつたが， 政善（F）が 3 例で，他の型に較べて炨機能所見

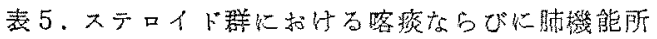
見の推移

\begin{tabular}{|c|c|c|c|c|c|c|c|}
\hline & \multirow{2}{*}{ 症例数 } & \multicolumn{3}{|c|}{ 愘疹所見の推移 } & \multicolumn{3}{|c|}{ 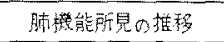 } \\
\hline & & SS & $S$ & $s$ & $F F$ & $E$ & $f$ \\
\hline I 型 & 14 & 0 & $\begin{array}{l}9 \\
(64.3)\end{array}$ & $5(35.7)$ & ${ }^{2}(14.3)$ & ${ }^{2}(14.3)$ & 10 \\
\hline II 型 & 9 & $\begin{array}{l}4 \\
(44.4)\end{array}$ & $(11.2)$ & $\begin{array}{l}4 \\
(44.4) \\
\end{array}$ & (11.2) & 0 & $\begin{array}{l}8 \\
(88.8) \\
\end{array}$ \\
\hline 证型 & 2 & 0 & ${ }^{1}(50,0)$ & $l_{(50.0)}$ & 0 & 0 & $2(100,0)$ \\
\hline II 型 & 4 & 0 & ${ }^{2}(50,0)$ & $2(50,0)$ & 0 & 3 & $(25.0)$ \\
\hline 柿 & 29 & $4(13.8)$ & $\begin{array}{l}13 \\
(44.8)\end{array}$ & {$\left[\begin{array}{l}12 \\
(41.4)\end{array}\right.$} & 3 & 5 (17.2) & (72.4) \\
\hline
\end{tabular}

の好転例が最も高率であつた。

D. 気管支抬張染群（表6 参照）

気管支拡張薬として 1-( 3，5-シヒドロキシフ ェニール)-2-イソプロピルアミノェタノールを 投与した57例の知床的分類は，第 I 型18例，第 II 型 22 例，第正型 9 例，第N型 8 例であつた。

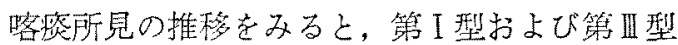
は改善を办ない（s）例が多く，第型および第 NV型においては䕰しい改善（S S)，改善（S）を 含めて整痰所見の好転したものが約半数に達して いた。

肺機能所見の推移をみると，第巫型に好転 (FF, F) 例が最も少なく，第I型に最高であつ たが，その内客をみると，第四型㧍よび第仅型に 著しい改善（FF）加比较的高率であつた。

E. その他の莧物群（表 7 参炤）

蛋白融解酵素であるは-キモトリプシンあるいは

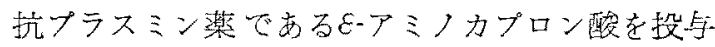

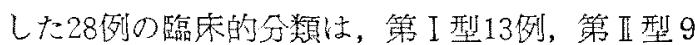

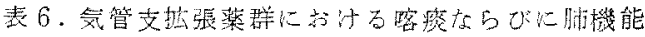
所見の推移

\begin{tabular}{|c|c|c|c|c|c|c|c|}
\hline & \multirow{2}{*}{ 经语数 } & \multicolumn{3}{|c|}{ 喀成所貝力㬈移 } & \multicolumn{3}{|c|}{ 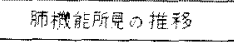 } \\
\hline & & $\$ S$ & 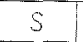 & 3 & $F F$ & $F$ & $f$ \\
\hline I 型 & 18 & $(5.6)$ & $\begin{array}{l}4 \\
(22.2)\end{array}$ & $\begin{array}{l}13 \\
(7222)\end{array}$ & $7(5.6)$ & $\begin{array}{l}9 \\
(5000)\end{array}$ & 8 \\
\hline II 型 & 22 & $7(31.8)$ & $6(27.3)$ & $90.9)$ & ${ }^{2}(91)$ & $\begin{array}{l}4 \\
(18.2)\end{array}$ & $1672.7)$ \\
\hline 型 & 9 & (11.1) & 0 & $\begin{array}{l}8 \\
(98.9)\end{array}$ & $\begin{array}{l}3 \\
(33.3)\end{array}$ & $(111)$ & $\begin{array}{l}5 \\
(55.6) \\
\end{array}$ \\
\hline 政㤠 & 8 & ${ }^{2}(250)$ & $\frac{2}{225.03}$ & $\begin{array}{l}4 \\
50.0)\end{array}$ & ${ }^{2}(25.0)$ & $I_{(12.5)}$ & 5 \\
\hline 棓 & 57 & $11(19.3)$ & $\begin{array}{l}12 \\
(21.1)\end{array}$ & $\begin{array}{l}34 \\
(59.6)\end{array}$ & $8(14.0)$ & 15 & $\begin{array}{l}34 \\
(59.7)\end{array}$ \\
\hline
\end{tabular}

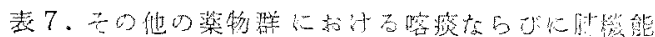
所胃の椎移

\begin{tabular}{|c|c|c|c|c|c|c|c|}
\hline & \multirow{2}{*}{ 症测刻 } & \multicolumn{3}{|c|}{ 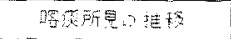 } & \multicolumn{3}{|c|}{ 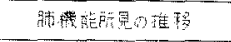 } \\
\hline & & $S S$ & 5 & s & $F F$ & $F$ & $f$ \\
\hline I 型 & 13 & 0 & 3 & $(76.9)$ & $2^{2}(154)$ & $\begin{array}{l}3 \\
(23.1) \\
\end{array}$ & $801.5)$ \\
\hline II 型 & 9 & 3 & $3(33.3)$ & 333.3 & $\theta$ & $\begin{array}{l}2 \\
(22.2)\end{array}$ & 777.8 \\
\hline III 羿 & 2 & 0 & 0 & $\frac{2}{(1000.0)}$ & 0 & 0 & 2 \\
\hline 取型 & 4 & 0 & $4(1000)$ & 0 & 0 & 0 & $4(100.0)$ \\
\hline 計 & 28 & $3(0.7)$ & $\begin{array}{l}10 \\
(7,5,7)\end{array}$ & 15 & 2 (7.1) & $\begin{array}{l}5 \\
(17.9)\end{array}$ & $\begin{array}{l}21 \\
(75.0)\end{array}$ \\
\hline
\end{tabular}




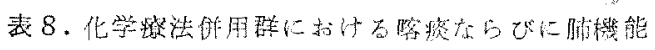
所兒の推移

\begin{tabular}{|c|c|c|c|c|c|c|c|}
\hline & \multirow{2}{*}{ 症例粒 } & \multicolumn{3}{|c|}{ 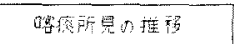 } & \multicolumn{3}{|c|}{ 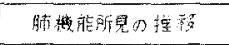 } \\
\hline & & 59 & 5 & $d$ & $F F$ & $F$ & $f$ \\
\hline I 型 & 16 & 5 & $\sigma_{(37.4)}$ & $\begin{array}{l}5 \\
(3 / 3)\end{array}$ & $t_{(6.3)}$ & $\begin{array}{l}6 \\
(37.4)\end{array}$ & $\begin{array}{l}9 \\
(56.3)\end{array}$ \\
\hline II 型 & 13 & $7(53.8)$ & $5(35.5)$ & $1(7,7)$ & ${ }^{2}(15.4)$ & 3 & $\begin{array}{l}8 \\
(61,5)\end{array}$ \\
\hline III 型 & 6 & $2_{(33,3)}$ & $(16.7)$ & $3(50,0)$ & $1(66.7)$ & $1(16.7)$ & ${ }^{4}(66.6)$ \\
\hline III 型 & 9 & $6_{(66.7)}$ & & $(11,1)$ & 5 & ${ }^{2}(22.2)$ & $2_{(22.2)}$ \\
\hline 計 & 44 & 20 & $\left(\begin{array}{l}14 \\
(31.8)\end{array}\right.$ & $\begin{array}{l}10 \\
(22.7)\end{array}$ & & $\begin{array}{l}12 \\
(27.3)\end{array}$ & $\begin{array}{l}23 \\
(52.2)\end{array}$ \\
\hline
\end{tabular}

例，第且型 2 例，第U型 4 例であつた。

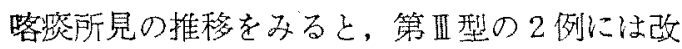
善がみられず（s），筹I型においても（s）が高

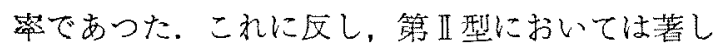
い改善（SS），改善（S）が各 $1 / 3$ の症例にみ られており，さらに第型においては（SS）と 制定された例はなかつたけれども，全例に好轾が みられていた。

肺機能所見の推移をみると，第四型および第W

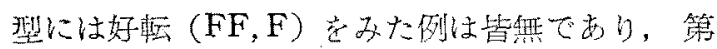

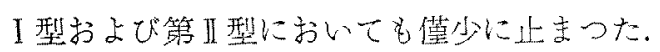

$\mathrm{F}$ ，化学療法併用群 (表 8 参䛲)

化学療法薬・ステロイドあるいはクロロ+ン

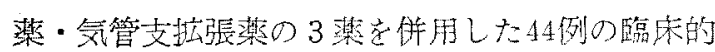

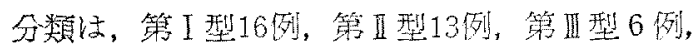
管 $\mathrm{V}$ 型 9 例であつた。

喀痰所見の推移をみると，A〜 $\mathrm{E} の$ 諸種薬物を 単独に使用した各群に较べて㦄れた成續を示して

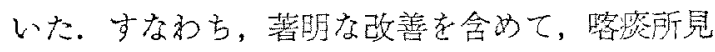
の好転をみたものは，第型型拉よび第、型におい ては90\%前後の高率に達し，第I型では約70\%， 第田型でも50\%であつた。しかも转明な改善は籍

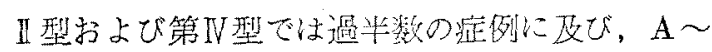
Eの各群で著明な改善をみることの少なかつた第 I型および第且型においても約30\%であつた。

肺機能所見は，喀疹所見にみられたような優秀 な成續とはいえなかつたが，第 $\mathbb{N}$ 型にちいて著明 应改善 (FF) 芯過半数の症例に達し, 改善 $(\mathrm{F})$ を合めると，約80\%の症例において好転がみられ たことは特異な成續と思われた。

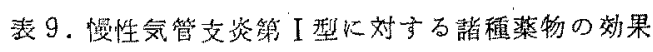

\begin{tabular}{|c|c|c|c|c|c|c|}
\hline \multirow[t]{2}{*}{$*$} & 著効 & 有効 & +1 & 有効 & 鰵募 & \multirow{2}{*}{ t十 } \\
\hline & SSFF & SSE SFP & SSf.Sf & $T_{\Delta F F \cdot \Delta F}$ & $\Delta f$ & \\
\hline 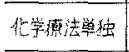 & $1(5.2)$ & $3(15.8)$ & $6(31.6)$ & 3 & $\begin{array}{l}6 \\
(31.6)\end{array}$ & 19 \\
\hline $200 \div$ & 0 & ${ }^{4}(25.0)$ & $4(25.0)$ & $3^{3}(18.7)$ & 5 & 16 \\
\hline ステロAト & 0 & $\hat{3}(21.4)$ & $6_{(42.9)}$ & $17.1)$ & $4(28.6)$ & 14 \\
\hline 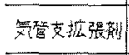 & 0 & $2(1.0)$ & $3(16.7)$ & $8_{(44.5)}$ & 5 & 18 \\
\hline 当口他の集刘 & 0 & $2(15.4)$ & $(7.7)$ & $\begin{array}{l}3 \\
(23.1) \\
\end{array}$ & $7(53.8)$ & 13 \\
\hline 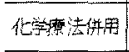 & $\overline{0}$ & $3(18.7)$ & $9(56,3)$ & $3(18.7)$ & ${ }^{\prime}(6.3)$ & 16 \\
\hline 計 & 1 (at) & 17 & 29002 & 21 & $\begin{array}{l}28 \\
(29.2)\end{array}$ & 96 \\
\hline
\end{tabular}

\section{VI. 慢性気管支炎諸型における諸種薬物の効果}

慢性気管支炎の諸型に対する諸種薬物の効果を みるため，以下のごとく喀淡所見と肺機能所見と を組み合わせた刵定法を採用した。

著効(SSFF)：喀痰ならびに肺機能所見の雨者 とも著しい改善のみられたもの.

有效 $(\mathrm{SSF} \cdot \mathrm{SFF} \cdot \mathrm{SF})$ ：喀㢞ならびに肺機能所 見ともに改善がみられたもの。

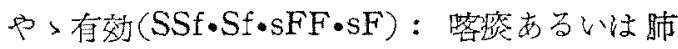
機能所見のいすれれか一方に改善のみられた \&

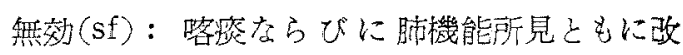
善のみられなかつたもの。

\section{A. 慢性気管支炎第 I型（表 9 参唱）}

慢性気管支炎第 I 型96例に対する，上述のごと き諸種莯物による治療効果を表 9 に一括して示し た、筹I型に対しては化学袮法併用群は著效例 こそみられなかつたけれども，16例中15例（93.8 \%)の高率に何ら加の程度の效果汃讃められた。 その他の群においても60〜70\%の症例に対して何 らかの效果があつたが， $\alpha$-キモトリプシンあるい はとーアミノカプロン酸を用いた群のみは過半数の 例艻無効に終つた。

效果を認めたもの>う古, 著效は化学寮法を单 独に使用した群の1例のみであり，有效之制定さ れた症例も各種蒋物群とも20\%以下であつた。落 零所見の改善によりやっ有効と制定された症例の 多かつたのは化学療法篻独・垪用両群およびステ ロイド群であり，肺機能所見の改善によりや>有 效乙刵定された症例证気管支抬張菜群に最も多加 


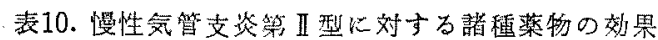

\begin{tabular}{|c|c|c|c|c|c|c|}
\hline & 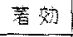 & 乵 & \multicolumn{2}{|c|}{ 地了有効 } & \multirow{2}{*}{\begin{tabular}{|c|c|c|} 
無奻 \\
sf
\end{tabular}} & \multirow{2}{*}{ 柿 } \\
\hline & SSFF & SSFGF & SST $S f$ & $\Delta F=A F$ & & \\
\hline 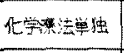 & 0 & $6,35.3)$ & $(1,4.7)$ & 0 & 0 & 17 \\
\hline クロ0+ & 0 & $\begin{array}{l}3 \\
(177,7)\end{array}$ & $\begin{array}{l}9 \\
62.99 \\
\end{array}$ & $1(5.9)$ & $\begin{array}{l}4 \\
(23.5) \\
\end{array}$ & 17 \\
\hline ステロ什 & 0 & 0 & $5(55,6)$ & (at.t) & 3033 & 9 \\
\hline 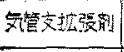 & 0 & $3(3.6)$ & $10(45,5)$ & $3_{(13.6)}$ & $\begin{array}{l}6 \\
(27.3) \\
\end{array}$ & 22 \\
\hline 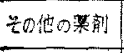 & 0 & $2(22.2)$ & $4(44.5)$ & 0 & $3(33.3)$ & 9 \\
\hline 化常清法供用 & $2(15.4)$ & $3(23,1)$ & $7(53.8)$ & 0 & $t(7.7)$ & 13 \\
\hline 譬 & ${ }^{2}(2,3)$ & 170.51 & $\begin{array}{l}46 \\
(52.9)\end{array}$ & $5(5.8)$ & $17(19.5)$ & 87 \\
\hline
\end{tabular}

表11. 慢性気管支资第而型氏対する諸種薬物の奻果

\begin{tabular}{|c|c|c|c|c|c|c|}
\hline & \multirow{2}{*}{$\frac{\text { 著謧 }}{\text { SSF }}$} & \multirow{2}{*}{ 市効 } & \multicolumn{2}{|c|}{ 斗南奻 } & \multirow{2}{*}{$\frac{\text { 効 }}{\Delta f}$} & \multirow{2}{*}{ 計 } \\
\hline & & & SSf.Sf & $\Delta F \cdot 3 F$ & & \\
\hline 北学㵔注算独 & 0 & 0 & {$[(20.0)$} & $2(40.0)$ & $2(40.0)$ & 5 \\
\hline クロロキン & 0 & $2(33,3)$ & ${ }^{2}(33.3)$ & 0 & $2(33: 3)$ & 6 \\
\hline スデロ任 & 0 & 0 & ${ }^{1}(50.0)$ & 0 & $(50.0)$ & 2 \\
\hline 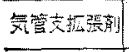 & 0 & 0 & $(11.2)$ & $4(44.4)$ & $4.44 .4)$ & 9 \\
\hline 元他他菜刘 & 0 & 0 & 0 & 0 & $2(1000)$ & 2 \\
\hline 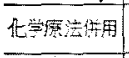 & 0 & $1_{(167)}$ & $2(33,3)$ & $1(16.7)$ & $2(33,3)$ & 6 \\
\hline 訫 & 0 & $3(1000)$ & $\begin{array}{l}7_{2} \\
(23,3)\end{array}$ & $7(23.3)$ & $\begin{array}{l}13 \\
(4334)\end{array}$ & 30 \\
\hline
\end{tabular}

つた.

\section{B． 慢性気管支炎第 II 型（表10参照）}

慢性気管支炎第 II 型87例について，同様に諸種

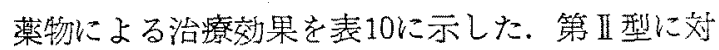
しては化学療法が卓越した効果を示しており，合 計30例のうち 1 例を除く他の29例に何らかの效果 が認方れた。しかも第左型における著效の 2 例

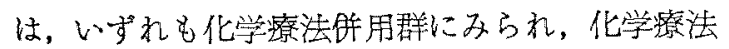
の2群において，や〉有效乙制定された18例はす べて咯痰所見の改善によるものであつた，氮管支

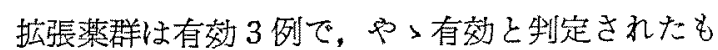
のが13例に達したが、その内容をみると、帽機能 所見の改善によるものはむしろ少なく，喀痰所見 の改善によるものが大部分を占るていた。 クロロ キン群，ステロイド群およびその他の楽物群にお いても，そのほとんぼが喀痰所見の改善によりや や有效と刵定されていた。

C. 慢性気管支炎第那型（表11参照）

慢性気管支炎第 型忹合計30例であつたが，著

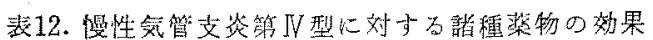

\begin{tabular}{|c|c|c|c|c|c|c|}
\hline & \multirow{2}{*}{ 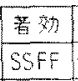 } & \multirow{2}{*}{ 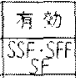 } & \multicolumn{2}{|c|}{ 䨋劯 } & \multirow{2}{*}{$\mid$\begin{tabular}{|l|} 
哭 \\
效
\end{tabular}} & \multirow{2}{*}{ 計 } \\
\hline & & & SSt. St & AFF.SF & & \\
\hline 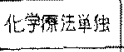 & 0 & 0 & $3(750)$ & 10 & $(250)\}$ & 4 \\
\hline $200 \div 7$ & 6 & $4(40.0)$ & $1(10.0)$ & $3(30.0)$ & $2(20.0)$ & 10 \\
\hline Zテロ゙イト & 0 & ${ }^{1} \cdot(250)$ & $I^{\prime}(25,0)$ & $2(50.0)$ & 0 & 4 \\
\hline 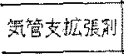 & 0 & ${ }^{2}(25,0)$ & ${ }^{2}(25,0)$ & $1(12.5)$ & 3 & 8 \\
\hline 之の他の梁剜 & 0 & 0 & $4(00,0)$ & 0 & 0 & 4 \\
\hline 化学源法併用 & $4 \quad 444.5$ & ${ }^{2}(22.23$ & ${ }^{2}\{22.23$ & $1(11.1)$ & 0 & 9 \\
\hline 竐 & $4(10.3)$ & $9(23.1)$ & $\begin{array}{l}13 \\
(33,3)\end{array}$ & $7(17.9)$ & 6 & 39 \\
\hline
\end{tabular}

效例はなく, 有效例もクロロキン群抢よび化学療 法併用群に 3 例みられたのみで，他の型に較べ治 療効果が劣つていた。や有效と制定された症例 については，クロロキン群およびステロイド群は

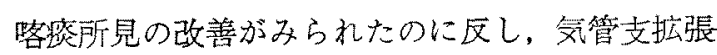
薬群においては，肺機能所見の改善によるもの が多かつた。その他の薬物を用いた 2 例はすべて 無效と制定された。

\section{D. 慢性気管支炎第U型（表12参照）}

慢性気管支炎第 $\mathrm{N}$ 型39例に対する諸程㭗物の効 果は表12のごとくである。第N型に効しては,化学 療法併用群が卓越した成績を示していた。すなる ち9例のうち4例までが著效，2例が有效，3例が

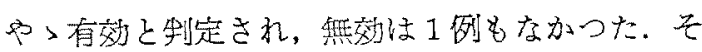
の他の群においては著效例はなく，有効例が此較 的多かつたのはクロロキン群であつた。また，第 II 型において肺機能の改善によるや〉有效例を認 わなかつたクロロキン群およびステロイド群は， 第 $\mathbb{V}$ 型においては逆に肺機能の改善によりや〉有 效と制定された例名多いようであつた，第型に おいてや〉有效と制定された例の多かつた化学療 法単独投与群むよびその他の薬物群は, 茖痰所見 の改善によって,や〉有效と刵定されたものであ つた。

\section{VII. 総括および考案}

気管支炎 (bronchitis) という言葉沈Badham ${ }^{6}$ (1808）によつて初めて用いられた病名である が，その後，定義・病因等に潹く考慮を払うこと なく，日常の疾患名として多くの臨床医家に用い 
られて来た，従つて気管支炎，なかんずく慢性気 管支炎という診断名にかんしては，人によりまた 国により，それでれや〉異なつた概念のもとに使 用されて来ている，たとえば，宾国のFletcher7 あるいはAmerican Thoracic Societyの見解8に よると，慢性気管支炎は氛管支における分泌過剩 を特徴之する疾患であつて，慢性あるいは区復す る咯痰を件なう喛濑が主症状であり，このような 状態を来たす他の原因が除外できれば，慢性気管 支炎と䛦断しうる充分の条件肪揃つたことになる としている・しかして英国のOswaldら早あるいは Stuart-Harris and Hanley ${ }^{10} の こ ゙ と く$, 上述の 症状の他に吸呼困難を加えている学者艺ある驾， わが国の中村ら ${ }^{11)}$ ，藤田ら ${ }^{12}$ を始めとする多くの 学者は，Fletcherの見解7)に賛意を表している.

Fletcherは，慢性気管支炎に対しては感染は必 すしも必要でないとの立場をとり，感染を繰り还

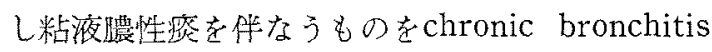
with infection,閉塞性換気障害索有するものを chronic bronchitis with obstructive lung diseaseとしている・すなわちFletcherは, infection およびobstructive lung disease 合併症と考え ているわけである.

ところで今回われわれが研究の效象とした誨分 又工場旧彷業員についてみると、いずれもイペ リットあるいはルイサイトの製造，または，去れ に関係のある作業に彷事した人々であつた。昭和 36年から37年にわたる565例の詳細な調查によれ ば，イペリットあるいはルイサイトの製造に従事 した人々の約 $80 \%$ は，今日もな抄激しい咳嗽上整 痰を有し，Fletcherの定義により慢性気管支炎と 診断して差支えない状態であり，一部にはsimple chronic bronchitisの定義を越え，さらに進展し たと思われる症例も含まれていた。この毒ガス製 造工場は日本における唯一の工場であつたので， わが国においては他に類例をみないものである が，諸外国の文献においても，職業的に专ガスに 暴露された症例の報告はなく、たが第一次大戦に おいてドイッ軍の用いたイペリットにより急性
傷客を憼つた連合軍兵士についての報告をみるの みである. 報告者の多くは，か〉る兵士にみられ る後遗症を慢性気管支炎己呼んで方り, Case and Lea $\left.{ }^{13}\right)$ は $81 \%$, Beebe ${ }^{14}$ は65\%という高い頻度で あつたとしている。

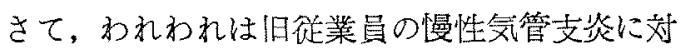
し，過去十余年の長期にわたり治療を継続してい るが，いまだ全治せしわえたと確信しうる症例に 接しえず，鍷治であるとの印象を受けている。そ こでわれわれは従来の治療を区省し，さらに有力 な治療体系を確立する目的で, 昭和37年以降系統 的な研究を開始した。しかして慢性気管支炎に対 する治療を，われわれは，

1. 気管支を刺激する要因よりの回避

2. 気道感染に対する治療

3. 肺機能改善を目標とする治療

の三つに大別しているが，慢性気管支炎の薬物療 法に当つては，気道感染扔よび肺機能障害の改善 に重点をおくべきであると考えている，そこでわ れわれは治療を開始寸るに先立方，各症例につい て自覚症状も聴取したが，とくに喀痰娭查を実施 して気道感染の強弱を知り，さらに肺機能検查に より閉塞性換気障害の有無を検討した。

かくして同じく慢性気管支炎と診断された症例 を，その時点における状態により4型に分けた。 すなわ的，慢性気管支炎第 I 型恃気道感染分著明 でなく，閉塞性換気障害も認められないものであ り、第比型は両所見とも著明なものとした。また 第型恃気道感染のみが，第型峌閉塞性換気障 害のみが明らかなものであつた。

また一方, 效果の制定も自覚症状の改善は一応 考虑に大れず，喀症および肺機能検查所見など， その改善客観的に評価しうるものに限定し，両 所見とも著しく改善したものを「著效」，両所見 とも改善したものを「有效」，いずれか一方のみ の改善を「队〉有效」，両所見々も改善のみられ なかつたものを「無效」とした。

さてその成团のいかん問わず，慢性気管支炎 を增覀せしめる最も重要な要素は感染であること は諸学者の等しく認めているところである．英国 
においては過去十数年にわたり，数多〈の報告15) がなされでおり，H. influenzaeとDiplococcus pneunoniaeの 2 者を起炎菌として重視している 傾向がある、ところがわが国においては，上述とは

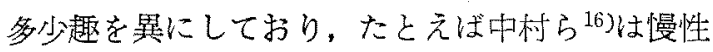
氛管支炎においては他の呼吸器疾息に較べると， 整痰中に白色ブドウ球菌の検出率方高く，膿性痰 では黄色ブドウ球菌の優位のものが多いと还べて

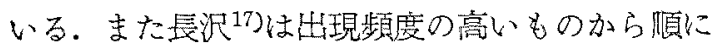
ならべると，綠連菌・肺炎双球菌・白色ブドウ球 菌である己述べている。本研究引の対象之なつた 慢性気管支炎65例の整痰培荃の結果，発見された 紐菌の主なものは，溶血性双球菌 $(86.4 \%)$, 溶連 菌 $(84.6 \%)$ ，ブドウ球菌 (36.9\%) であつた。と もあれ慢性気管一支炎の起炎菌は決して一様のもの ではなく, 従つて化学療法薬としては此較的広範 困な抗菌スペクトルを有するものが理想的であ

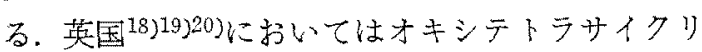
ン拐よびクロラムフェニコールを用いる学者が多 いようであつた。われわれも化学潦法葙としては テトラサイクリンとオレアンドマイシンの合羭, 内服ペニシリン薬および持続性サルファ葙疗に゙ を選び，抗炎症作用を期待しうるものとしてク ロロキン薬・副腎皮質ステロイド・抗プラスミン

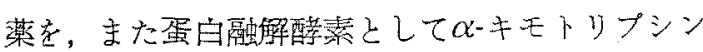
を、さらに気管支拡張薬索加え，かつる薬物を単

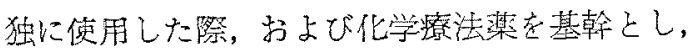

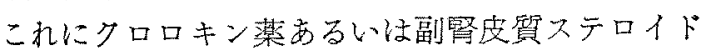
宁よび気管支昖張薬を配した 3 程㭗物による併用

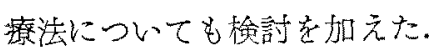

その結果, 諸種薬物の単独投与群についてみる 々，化学療法蒀は慢性気管支炎の第四型を除く他 の各型に娰して高率な客痰所見の改善をもたら し，肺機能所見においてを第IV型を除く他の3 型 に対して 30〜40\%の例に改善を示した，彷つて総 合制定において好転例(著效・有效・や>有效の 合䛅）は第II型で 100\%，第I型および第IV型で $70 \%$ 前後に達している.

クロロキン楽抒よびスラ゙ロイド薬は慢性気管支

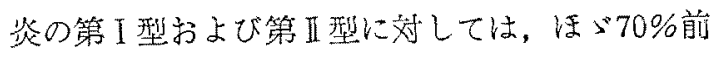
後の症例に好転を諗めたが，第型においては化 学療法薬によつてえられた成績には及改ばなつ た。しかしな加ら他の桼物による效果が期待し難 かつた慢性気管支策第型においては，フロロキ

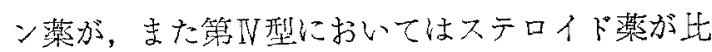
較的良好な成績を示している。

気管支搪張薬は一般的にいつて他の薬物に較べ ると眝機能所見の改善をみる例が多くっことに慢

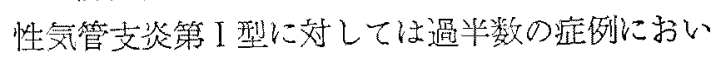
て改善がみられ，他の薬物により比較的に改善を みる例の少なかつた第正型に対しても44.4\%に澾 していたままた喀痰所見については受管支搪張薬 が化学療法薬のごとく，一次的に改善をもたらす ことは期待していなかつたのであるが，慢性気管 支炎第II型抒よび第N型に対しては肺機能所見の 改善をむしろ上回る程度の哌好な成續准得られて おり，分班物の排出が容易となつたためと考えら れた。促つて絵合制定に扮いて，何らかの効果を 誋めた症例は第I型および第扛で70\%に達して いた。

蛋白融解酵素あるいは抗プラスミン萫を用いた 群においては，咯痰所見に扔いても，盿機能所見

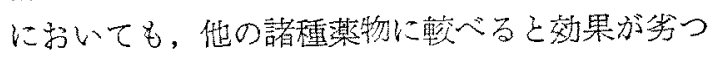
ていた，往つて総合制定において好転をみた症例 数当他の諸種㭗版に較べ低率であつた。

化学療法と抗炎定薬および気管支拉張菜の3藻 妨併用した群においては，慢性気管支炎のいずれ の型においても，他の諸種薬物群に比へ，喀跀・ 肺機能の再所見の改善が高率であつた，従つて総 合判定において好転例の合計は，慢性気管文炎第 壮型に扔いては 100\%，第】型方よび第型では 90\%以上であり，他の楽物群で效果の最も劣つて いた第四型でも $66.7 \%$ を占めていた。

以上，諸種薬物による喀痰所見・肺機能所見の 改善およびその雨者によつて行なつた総合制定の 結果，何らかの効果を認めた頻度について総括的 な記載を行宗つた。しかしながら，る楽物を传用 して気管支にお打炎症およびるれに伴なう変化 


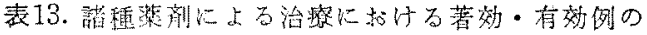
比新

\begin{tabular}{|c|c|c|c|c|c|}
\hline & \multicolumn{4}{|c|}{ 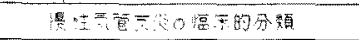 } & \multirow{2}{*}{ 部 } \\
\hline & $I \equiv$ & I & 型型 & IV 型 & \\
\hline 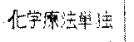 & 21.0 & 85.3 & 0 & 0 & 22.2 \\
\hline クロロキフ & 250 & 17.7 & 33.3 & 40.0 & 26.5 \\
\hline ステロ价 & 21.4 & 0 & 0 & 25.0 & 13.8 \\
\hline 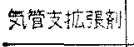 & $11.0^{\prime}$ & 13.6 & 0 & 25.0 & 12.3 \\
\hline 艺の他の簒搉 & 15.4 & 22.2 & 0 & 0 & 14.3 \\
\hline 化学璄法侻黑 & 18.8 & 38.5 & 12.7 & 66.7 & 34.1 \\
\hline$\mp 5$ & 18.8 & 21.8 & 10.0 & 33.4 & 21.0 \\
\hline
\end{tabular}

が著しく改善された場合，それはまず喀痰所見の 改善となつて現われ，ひいては肺機能所見も改善 されてしかるべきであると考えられる。かっる観 点から，総合制定における著效拐よび有效例のみ

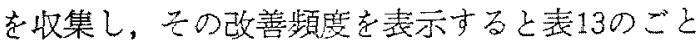
くである。す斿ち慢性気管支炎においては，有效 例以上をとると，各型を通じ一般的にいつて治療 成績は低率であることが制る。しかして,慢性気管 支炎第Ｉ型に詨しては，化学療法䒠・クロロキン 薬・ステロイド楽などは，ほぶ同程度に有効であ りこの型に扔いては化学療法併用群はとくにす ぐれた成續を示してはいない，慢性気管支炎第 II型は気道感染の高度な型であり，予想した通 り化学療法の2 群に最高の成績が得られている。 しかしながらこの型においても化学療法併用 群は単独投与群に比しとくにすぐれた成續は示し

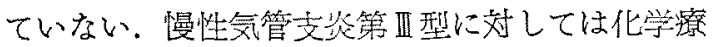
法・気管支昖張莧などは著效・有效例がともにな く、クロロキン薬が少数ながら優れた成績を示し ていた。慢性気管支览第IV型においては化学療法 単独投与群では著效・有效例が皆無であつたが， 併用群においては66.7\%という高い頻度であつた ことは注目を惹いている。その他ではクロロキン 萫が比較的良好な成續を示している。これを要す るに，慢性気管支炎第 I型に対しては，いすれれの

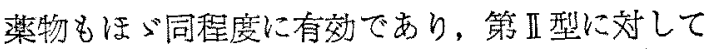
は，化学療法薬による治療が主体となるべきであ り，第四型に対しては，クロロキン薬が試みられ てょく，第W型に対しては，化学療法薬を基幹と
し，抗炎症薬・気管支拡張薬等の併用が望ましい といえるであるう。

上述したところをさらに要的すると，同じく慢 性気管支炎之診断しうる症例においても，気道感 染・閉塞性換気障害の面上り分類し，それに応じ た薬物を選択するならば，難治である本症の治療 成綨をいくらかでも向上せしめるのに役立つので はない加と考えられる。このような意味で，今 回，われわれの行なつた慢性気管支炎に対する臨 床的分類は，試みてしかるべき方法の一つと考え られる。

さて、かくのごとき治潦を目標とした慢性気管 支炎の分類は促来全く行なわれておらず，強いて いうならぼFletcherの分類が比較的われわれの意 因しているところに近いものといえよう。すなわ ち，われわれの慢性気管支第厂型はFletcherの いう simple chronic bronchitisに相当するもので あり，第II 型はchronic bronchitis with infection に似た状態と考えてよく，さらに第四型および第 VV型はchronic bronchitis with obstructive lung diseaseの範噚にあるものと考えられる。しかし ながら，われわれの踏床的分類は，あくまでも慢 性気管支炎の経過中における，西る時点の状態を 卒值に表現し，行なうべき治療方針をうるための 分類である、従つて治療の結果，ある型より他の 型へ移行することもありうるわけであり，この点 において上述したFletcherの分類とはその目的を

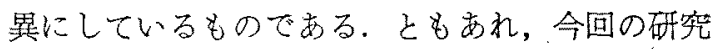
によりわれわれの臨床的分類の有用性を立証し えたものと考えている。

\section{VIII. 結 論}

今回われわれは慢性文管支炎を気道感染の强弱 および閉塞性換気障害の有無により次の 4 型に分 けた。すなわち，第I型とは，咯痰検查において気 道感染の所見が著明でなく、スパイログラフィー により閉塞性換気障害も認められないものであ り，第 $1 V$ 型は両所見とも著明なものとした。ま た，第型は気道感染のみを，第正型は閉塞性換 気障害のみを明らかなものとた。しかして、こ 
のような臨床的分類を定めた目的は，慢性受管支

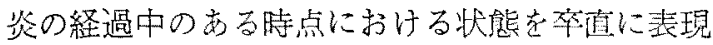

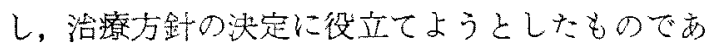
つた.

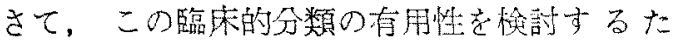

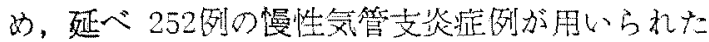
が，あらかじか症例㔺上迢した 4 型に分颣し，化

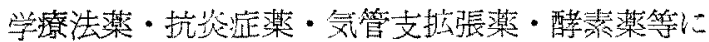
より 4 週間治療学行なつた。 その結果, 慢性気管支

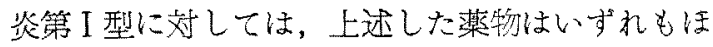

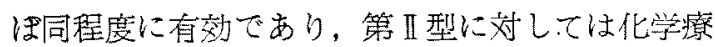
法薬による治療が最民有效で，第血型に効しては クロロキン菒が虔い成結を示し，第N梨に効して は化学寮法薬を基幹上し，抗炎是㴡・気管支搪張 薬の併用が卓越した效果走登揮した。

このようなこと办ら，慢性気管支炎に对するわ れわれの臨床的分類は治癔方針を決定し，摹治已 されている本症の治療成續の向上に資するなど， その有用性克立証し得たものと考えている。

\section{参考文献}

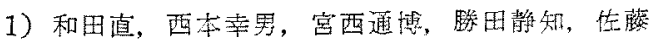
哲也，末田敏：ラウンドーブルコンフナランス

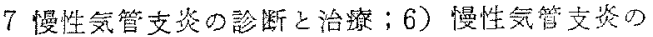

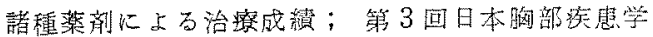

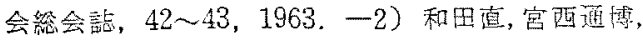

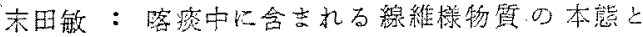

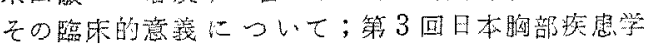
会総会誌, 67, 1963. -3) Wada S., Yamada, A., Nishimoto, Y., Tokuoka, S., Miyanishi, S., Katsuta, S., Umisa, H., Nishiki, M., Nagai, M.: Review of Okunojima Poison Gas Factory regarding occupational environment: Hiroshima J. Med. Sci. 11 ( 3 ) : 75 80, 1962. 一 4) 和旺直,

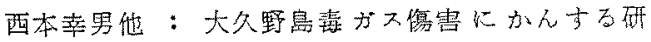
究(第 3 報) 毒ガス賃言としての慢性気管支炎; 日 内会誌, 52 (5)：472 473,1963, 一5) 和田直, 山田明，西茶幸男，德四昭治，宮西道博，腾田静

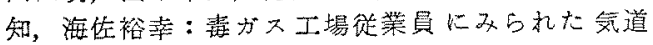
癌以ついて；広鼻医学，16(8)：728～745, 1963. -6) Badham, C.: Observation on the inflam- matory affections of the mucous membrane of the bronchiole, 1808, cited by Oswald. -7) Fletcher, C.M.: Chronic bronchitis, Its prevalence, nature, and pathogenesis; Amer. Rev. resp. Dis., 80: 483 494, 1959. -8) American Thoracic Society: Statement by the Commettee on Diagnostic Standards for Non-tuberculous Respiratory Diseases; Amer. Rev. resp. Dis., 85 : 762 769, 1962. -9) Oswald, N.C. et al.: Clinical pattern of chronic bronchitis ; Lancet 1953 . II, $639 \sim 643,1953 .-10)$ Stuart-Harris, C.H., Hanley, T.: Chronic bronchitis, emphysema, and cor pulmonale; The William and Wilkins Co., Baltimore, Maryland, 1957. -11) 中村隆, 滝息任，金野公郎：慢性気笛支炎の概念之最近の 勘向について; 胡疾慗の研究の進来, 32号, 33 42, 1962. -12) 霜田真之助, 出中元一, 吉网一郎: 慢性気管支炎阙する2，3の関題；日本監床，21 (5) : $851 \sim 856,1963 .-13$ ) Case, R.A.M., Lea, A.G.: Mustard gas poisoning, chronic bronchitis and lung cancer; An investigation into the possibility that poisoning by mustard gas in the 1914-18 war might be a factor in the production of neoplasia; Brit. J. prev. soc. Med., 9 (2) : 62 72, 1955. -14) Beebe, G. W.: Lung cancer in World War I veterans: Possible relation to mustard-gas injury and 1918 influenza epidemic; J. nat. Cancer Inst.; 25 (6) : 1231 1253, 1960. - 15) Edwards, G., Buckley, A.R., Fear, E.C., Williamson, G.M., Zinnemann, K.: Adult chronic bronchitisThe infective factor and its treatment; Brit. med. J., 1957-II, 259 264, 1957. -16) 中村 隆：慢性氮管支炎症候群；眴部疾㭧，7(9): 1107

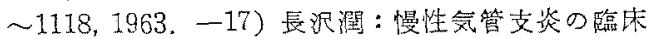
像及す゚灭の治療；最新医学，15(8):2015 2023， 1960. -18) Fear, E.C., Edwards, G.: Antibiotic regimens in chronic bronchitis; Brit. J. Dis. Chest, 56 ( 4) : 153 162, 1962. -19) Helm, W.H., May, J.R.; Livingstone, J.L.: Long-term oxytetracycline (Terramycin) therapy in advanced chronic respiratory infection; Lancet, 267 : 630-633, 1954. -20) Francis, R.S.: Spicer, C.C.: Chemotherapy in chronic bronchitis, influence of daily penicillin and tetracycline on exacerbations and their cost; Brit. med. J., 1960- I, $\quad 297 \sim 302,1960$. 